\title{
PERAN PEREMPUAN DAN STRATEGI KEBERLANJUTAN NAFKAH RUMAHTANGGA PETANI HORTIKULTURA KABUPATEN KONAWE
}

\author{
Israwati $^{(1)}$, Saediman ${ }^{2)}$, Nur Rahmah ${ }^{2)}$ \\ ${ }^{1)}$ Program Studi Magister Agribisnis Universitas Halu Oleo \\ ${ }^{2)}$ Dosen Tetap Fakultas Pertanian Universitas Halu Oleo, Kendari
}

Naskah diterima: 14 November 2017

Naskah direvisi: 29 Desember 2017

Disetujui diterbitkan: 22 Februari 2018

\begin{abstract}
This study was done in Lalonggotomi and Ahuawatu village, Pondidaha subdistrict of Konawe Regency with purposes : 1) described the role of woman in horticultural farmer's household in Konawe Regency; 2) described the strategy used for the household expenses continuity of horticultural farmer in Konawe regency. The results of the research were : 1) the woman role in Lalonggotomi and Ahuawatu was fairly high with $84 \%$, this showed that woman who do an activity such as reproductive, productive and social reached $84 \%$ from total number of informant; 2) strategy done for the continuity of household expenses were: a) Creation of farming expenses source with the utilization of farming sector effectively and efficiently, increasing number of employee, the us of recent technology innovation and land expension; $b$ ) double expenses pattern, beside helping the husband to work in the farm. there were also daily necessity's shop, catering, and vegetable distributor, sewing and rise selling; $c$ ) the utilization of loan and; d) Asset utilization.
\end{abstract}

Keywords: household woman's role household expenses continuity strategy.

Intisari: Studi ini dilaksanakan di Desa Lalonggotomi dan Desa Ahuawatu Kecamatan Pondidaha Kabupaten Konawe dengan tujuan: 1) mendeskripsikan peran perempuan dalam rumahtangga petani hortikultura di Kabupaten Konawe; 2) mendeskripsikan strategi yang digunakan untuk keberlanjutan nafkah rumahtangga petani hortikultura di Kabupaten Konawe. Hasil studi menunjukkan bahwa: 1) peran perempuan di Desa Lalonggotomi dan Desa Ahuawatu tergolong kategori tinggi dengan persentase $84 \%$, ini menunjukkan bahwa perempuan yang melakukan kegiatan baik peran reproduktif, produktif dan sosial mencapai $84 \%$ dari jumlah total informan; 2) strategi yang dilakukan untuk keberlanjutan nafkah rumahtangga berupa: a) rekayasa sumber nafkah pertanian, dengan pemanfaatan sektor pertanian secara efektif dan efisien, penambahan tenaga kerja, menggunakan inovasi teknologi terbaru serta perluasan lahan garapan, b) pola nafkah ganda, selain membantu suami kerja di lahan ada juga yang membuka warung sembako, menjual makanan jadi, menjual sayur keliling, menjahit dan menjual beras, c) pemanfaatan pinjaman dan, d) pemanfaatan Asset.

Kata kunci: peran perempuan rumahtangga dan strategi keberlanjutan nafkah rumahtangga.

\section{PENDAHULUAN}

Perempuan sebagai salah satu anggota keluarga, seperti juga anggota keluarga yang lain mempunyai tugas dan fungsi dalam mendukung keluarga. Sejak dulu sampai sekarang masih ada anggota keluarga yang menganggap bahwa tugas perempuan dalam keluarga hanya melahirkan keturunan, mengasuh anak, melayani suami dan mengurus rumahtangga. Dalam perkembangannya sekarang, ternyata tugas dan peran perempuan dalam kehidupan keluarga semakin berkembang lebih luas lagi. Perempuan saat ini tidak hanya berkegiatan di dalam lingkup keluarga, tetapi banyak diantara 
bidang-bidang kehidupan di masyarakat membutuhkan sentuhan dan kehadiran perempuan dalam penanganannya. Peran perempuan untuk ikut menopang kehidupan dan penghidupan keluarga semakin nyata (Sumarsono dkk, 1995). Dalam kehidupan keluarga, perempuan tidak hanya berperan sebagai ibu rumahtangga tetapi juga melakukan kegiatan produktif untuk menambah penghasilan guna meningkatkan kesejahteraan keluarga.

Pada zaman modern saat ini, seorang perempuan dituntut untuk kreatif, sabar, ulet dan tekun dalam mencapai kesejahteraan keluarga. Banyak hal yang telah dilakukan perempuan sebagai penopang ekonomi keluarga dengan cara berwirausaha, bekerja di perusahaan swasta maupun pemerintah, bahkan menjadi kuli kasar ataupun mengerjakan pekerjaan lainnya yang biasa dilakukan oleh laki-laki. Disinilah terlihat bahwa seorang perempuan sangat berperan dalam pemberdayaan ekonomi keluarga guna mencapai kesejahteraan keluarga. Perempuan dapat berperan ganda, disamping tugas pokoknya sebagai pengurus rumahtangga, juga membantu perekonomian keluarga, tentu dengan izin suaminya agar tidak menimbulkan konflik dalam rumahtangga. Agar keberlanjutan nafkah rumahtangga tetap terjaga, perlu adanya strategi untuk mengatasinya. Strategi nafkah meliputi aspek pilihan atas beberapa sumber nafkah yang ada di sekitar masyarakat. Semakin beragam pilihan sangat memungkinkan terjadinya strategi nafkah. Secara jelas dalam bidang pertanian digambarkan dengan adanya pola intensifikasi dan diversifikasi. Selain adanya pilihan, strategi nafkah mengharuskan adanya sumber daya manusia dan modal. Pola hubungan sosial juga turut memberikan warna dalam strategi nafkah. Pola relasi patron-klien dianggap sebagai sebuah lembaga yang mampu memberikan jaminan keamanan subsistensi rumahtangga petani (Crow, 1989). Alasan utama melakukan strategi nafkah ganda pada rumahtangga berbeda pada masing-masing lapisan. Pada rumahtangga lapisan atas, pola nafkah ganda merupakan strategi akumulasi modal dan lebih bersifat ekspansi usaha. Sedangkan pada lapisan menengah, pola nafkah ganda merupakan upaya konsolidasi intuk mengembangkan ekonomi rumahtangga. Sebaliknya pada lapisan bawah, pola nafkah ganda merupakan strategi bertahan hidup pada tahap subsistensi dan sebagai upaya untuk keluar dari kemiskinan (Sajogyo, 1982).

Kabupaten Konawe selain sebagai sentra tanaman padi sawah juga cukup berpotensi untuk pengembangan tanaman hortikultura utamanya tomat, cabai dan sayuran. Untuk itu peran perempuan sangat diperlukan untuk ikut serta berperan dalam membantu perekonomian keluarga dengan ikut terlibat langsung dalam kegiatan agribisnis hortikultura. Perempuan di Desa Lalonggotomi dan Desa Ahuawatu menganggap bahwa mereka dapat meringankan beban suami dalam hal ekonomi tanpa meninggalkan kewajibannya sebagai pengurus rumahtangga, dengan membagi waktu untuk anak dan keluarganya. Hal itu mereka lakukan untuk mencapai keluarga yang makmur sejahtera sehingga mereka dapat memenuhi kebutuhan keluarga.

Berdasarkan latar belakang pemikiran, maka masalah yang ingin dikaji adalah sebagai berikut: 1) mendeskripsikan peran perempuan dalam rumahtangga petani hortikultura, 2) mendeskripsikan strategi yang digunakan dalam keberlanjutan nafkah rumahtangga petani hortikultura

\section{TINJAUAN PUSTAKA}

\section{Peran}

Peran adalah segala sesuatu oleh seseorang atau kelompok orang dalam melakukan suatu kegiatan karena kedudukan yang dimilikinya (Soekanto, 1992). Peranan adalah seperangkat harapan yang dikenakan pada masyarakat yang menempati kedudukan sosial tertentu. Manusia sebagai makhluk sosial memiliki kecenderungan untuk hidup berkelompok. Dalam tahapan berkelompok tersebut terjadi suatu interaksi antar manusia. Munculnya interaksi diantara mereka menunjukkan bahwa mereka saling ketergantungan satu sama lain. Pada kehidupan suatu masyarakat akan muncul adanya peran, baik peran perorangan maupun peran kelompok. Peran merupakan aspek yang dinamais dari kedudukan ini (status) seseorang. Apabila seseorang melaksanakan hak dan kewajibannya sesuai dengan kedudukan- 
nya, maka hal ini berarti ia menjalankan suatu peranan. Peranan lebih banyak menekankan fungsi, penyesuaian diri dan sebagai suatu proses (Soekanto, 1992).

Peranan adalah suatu konsep perihal apa yang dapat dilakukan individu yang penting bagi struktur sosial masyarakat, peranan meliputi norma-norma yang dikembangkan dengan posisi atau tempat seseorang dalam masyarakat, peranan dalam arti ini merupakan rangkaian peraturan-peraturan yang membimbing seseorang dalam kehidupan kemasyarakatan (Soekanto, 1992).

Sebagai perempuan yang telah menikah mempunyai peran dalam keluarga inti sebagai istri, sebagai pengurus rumahtangga dan sebagai pencari nafkah. Pada umumnya dirasakan sebagai tugas utama dari seorang perempuan yang terkait dalam gambaran perkawinan. Dalam tiga peran tersebut, perempuan memberikan diri sepenuhnya demi kesejahteraan bagi keluarganya. Banyak perempuan merasa tidak puas dalam ketiga peran di atas dan sering keadaan ekonomi keluarganya menuntut untuk bekerja di luar, atau mencari suatu kegiatan yang menambah penghasilan keluarganya (Gould dan Kolb dalam Lubis, 1989).

.Manfaat bekerja bagi perempuan adalah :

1. Mendukung ekonomi rumahtangga

2. Meningkatkan harga diri dan pemantapan identitas

3. Relasi positif dan sehat terhadap keluarga

4. Pemenuhan kebutuhan sosial, berbagai perasaan, pandangan dan solusi

5. Peningkatan ketrampilan dan kompentensi yang disesuaikan dengan tuntutan tanggung jawab, tuntutan keterampilan dan kompetensi (Gould dan Kolb dalam Lubis, 1989).

\section{Peran Perempuan dalam Ekonomi Rumahtangga}

Peran perempuan secara umum memiliki tiga fungsi utama yang sangat berkaitan yaitu fungsi reproduksi, fungsi sosialisasi dan fungsi produksi. Fungsi reproduksi, sering dihubungkan dengan hak dan kewajiban sekaligus sebagai simbol kelebihan dan kelemahan perempuan. Fungsi sosialisasi berkaitan erat dengan fungsi dan tanggung jawabnya dalam mempersiapkan anak-anaknya masuk ke dalam pergaulan masyarakat luas, dimana pengasuhan dan pendidikan boleh dilakukan oleh orang lain, tetapi tanggung jawabnya tetap terletak pada seorang perempuan. Fungsi produksi berkaitan dengan fungsi ekonomis perempuan, sejalan dengan kemajuan zaman peningkatan kesempatan dan pendidikan memungkinkan perempuan tidak hanya berperan ekonomis secara tidak langsung tetapi dapat langsung menerima hasil, baik berupa uang ataupun barang sebagai imbalan dalam melakukan pekerjaan (Todaro dalam Forddanta, 2012).

Perempuan masuk dalam dunia kerja secara umum, biasanya terdorong untuk mencari nafkah karena tuntutan ekonomi keluarga yang terus meningkat, dan tidak seimbang dengan pendapatan yang tidak ikut meningkat. Hal yang banyak terjadi pada lapisan masyarakat bawah, bisa kita lihat bahwa kontribusi perempuan terhadap penghasilan keluarga dalam lapisan menengah kebawah sangat tinggi. Ada dua alasan pokok yang melatarbelakangi keterlibatan perempuan dalam bekerja adalah: (1) keharusan, dalam artian sebagai refleksi dari kondisi ekonomi rumahtangga yang rendah, sehingga bekerja keras dalam meningkatkan pendapatan ekonomi rumahtangga adalah sesuatu yang sangat penting. (2) Memilih untuk bekerja sebagai refleksi dari kondisi sosial ekonomi pada tingkat menengah ke atas. Bekerja bukan semata-mata diorientasikan untuk mencari tambahan dana untuk ekonomi keluarga tapi merupakan salah satu bentuk aktualisasi diri mencari wadah untuk sosialisasi (Suratiah dkk, 1999).

\section{Strategi Keberlanjutan Nafkah}

Strategi merupakan penetapan suatu pilihan dari beberapa pilihan yang ada. Dengan demikian, strategi mencakup beberapa aspek antara lain: (1) adanya pilihan; (2) mengikuti pilihan berarti memberikan perhatian pada suatu pilihan dan mengurangi perhatian pada pilihan yang lain; (3) dengan merencanakan strategi yang mantap, ketidakpastian (posisi) yang dihadapi seseorang dapat dieliminir: (4) strategi dibangun sebagai respon terhadap tekanan hebat yang menerpa seseorang; (5) harus ada sumberdaya dan pengetahuan sehingga seseorang bisa membentuk dan mengikuti berbagai 
strategi yang berbeda; (6) strategi biasanya merupakan keluaran dari konflik dan proses yang terjadi dalam rumahtangga (Crow dalam Dharmawan, 2001).

Strategi nafkah rumahtangga merupakan suatu proses dimana rumahtangga membangun suatu kegiatan dan kapabilitas dukungan sosial yang beragam untuk bertahan hidup atau meningkatkan taraf hidupnya.. Strategi nafkah petani digolongkan setidaknya menjadi 3 golongan besar. Ketiga strategi tersebut adalah:

1. Rekayasa sumber nafkah pertanian yang merupakan usaha pemanfaatan sektor pertanian agar lebih efektif dan efisien, baik melalui penambahan input eksternal berupa tenaga kerja atau teknologi (intensifikasi) maupun dengan memperluas lahan garapan pertanian (ekstensifikasi)

2. Pola nafkah ganda, yang merupakan usaha yang dilakukan dengan cara mencari pekerjaan lain selain sektor pertanian untuk menambah pendapatan (diversifikasi pekerjaan).

3. Rekayasa spasial, merupakan usaha yang dilakukan dengan cara mobilisasi/perpindahan penduduk baik secara permanen maupun sirkuler atau migrasi (Scoones, 1998).

\section{Pembagian Peran di dalam Rumahtangga Petani}

Ada tiga kategori peranan perempuan yaitu: (1) peranan produktif, yakni peranan yang dikerjakan perempuan untuk memperoleh bayaran/upah secara tunai atau sejenisnya. Termasuk produksi pasar dengan suatu nilai tukar, dan produksi rumahtangga/subsisten dengan nilai guna, tetapi juga suatu nilai tukar potensial, contohnya: kegiatan bekerja baik di sektor formal maupun informal, (2) peranan reproduktif, yakni peranan yang berhubungan dengan tanggung jawab pengasuhan anak dan tugastugas domestik yang dibutuhkan untuk menjamin pemeliharaan dan reproduksi tenaga kerja yang menyangkut kelangsungan tenaga, contoh: melahirkan, memelihara dan mengasuh anak, mengambil air, memasak, mencuci, membersihkan rumah, (3) peranan pengelolaan masyarakat dan politik. Peranan ini dibedakan kedalam dua kategori berikut: (a) peranan pengelolaan masyarakat (kegiatan sosial), yang mencakup semua aktivitas yang dilakukan dalam tingkat komunitas sebagai kepanjangan peran reproduktif, bersifat sukarela (volunteer), (b) peranan pengelolaan masyarakat politik, yakni peranan yang dilakukan pada tingkat pengorganisasian komunitas pada tingkat formal secara politik, biasanya dibayar (langsung ataupun tidak langsung), dan meningkatkan kekuasaan atau status (Fakih, 1996).

\section{Agribisnis Hortikultura}

Agribisnis Pertanian merupakan usaha yang berkaitan erat dengan sistem pengolahan dan kegiatan produksi di sektor pertanian yang meliputi pengelolaan produksi pertanian itu sendiri maupun pengelolaan hasil produksi. Agribisnis bukanlah semata-mata hanya berkutat pada usaha produksi hasil pertanian saja, namun agribisnis meliputi beberapa tahapan kompleks yang satu sama lainnya akan berkesinambungan, meliputi : penyediaan bahan baku (bibit), penanganan pasca panen, pengolahan hasil panen dan pemasaran hasil panen. Tujuan dari pembangunan pertanian agribisnis adalah untuk:

1) aktivitas ekonomi pedesaan

2) meningkatkan pendapatan dan kesejahteraan para petani dengan penggunaan lahan dan metode pendekatan agribisnis dalam sistem pertanian.

3) meningkatkan daya saing produk pertanian dalam pasar global sehingga nilai ekspornya dapat menjadi lebih tinggi

4) menciptakan sistem ketahanan pangan dan budaya mengkonsumsi pangan lokal

5) membangun Meningkatkan lapangan kerja di pedesaan

\section{METODE STUDI}

\section{Paradigma Studi}

Studi ini menggunakan paradigma post-positivisme yang merupakan studi kualitatif yang bersifat deskriptif. Pada studi kualitatif yang bersifat deskriptif, data yang dikumpulkan umumnya berbentuk 
kata-kata, gambar. Data tersebut meliputi transkrip wawancara, catatan di lapangan, foto-foto dan dokumen pribadi. Sebagaimana yang menjadi corak dari studi kualitatif deskriptif, bahwa studi kualitatif tidak hanya menetapkan studinya hanya berdasarkan variabel studi tetapi keseluruhan situasi sosial yang diteliti yang meliputi aspek tempat ( place), pelaku (actor) dan aktivitas (activity) yang berinteraksi secara sinergis dengan objek yang diteliti. Studi kualitatif (qualitative research) merupakan metode-metode untuk mengeksplorasi dan memahami makna yang oleh sejumlah individu atau sekelompok orang dianggap berasal dari masalah sosial atau kemanusiaan, bertujuan untuk mengungkapkan proses, interpretasi makna dan mengarah pada pengungkapan keadaan atau perilaku individu yang terobsesi secara holistik.

\section{Pendekatan dan Desain Studi}

Studi ini menggunakan pendekatan kualitatif metode deskriptif, untuk menjelaskan fenomena peran perempuan dan strategi keberlanjutan nafkah rumahtangga petani hortikultura di Kecamatan Pondidaha Kabupaten Konawe. Studi deskriptif kualitatif dimaksudkan untuk memberikan gambaran serta penjelasan secara komprehensif (mendeskripsikan) beberapa fenomena sosial yang ada hubungannya dengan konsep utama yang dibahas. Adapun pendekatan kualitatif yang dimaksud adalah untuk menelusuri latar belakang dari fenomena yang diteliti sebagai suatu konsep yang utuh.

Perhatian utama pada pendekatan kualitatif, yaitu senantiasa menekankan pada prosedur studi yang menghasilkan data atau informasi kualitatif, yang memungkinkan para peneliti memahami masyarakat secara personal dan memandang mereka sebagaimana mereka sendiri mengungkapkan pandangan dunianya. Ciri studi kualitatif berupaya memahami gejala sosial yang tidak mungkin dihitung secara tepat (Garna, 2004). Studi kualitatif menghasilkan data deskriptif berupa kata-kata atau kesan dari pelaku yang diamati

(Creswell, 1994).

Metode kualitatif ini digunakan karena: (1) menyesuaikan metode kualitatif lebih mudah apabila berhadapan dengan kenyataan ganda; (2) metode ini menyajikan secara langsung hakikat hubungan antara peneliti dengan informan; (3) metode ini lebih peka dan lebih dapat menyesuaikan diri dengan banyak penajaman pengaruh bersama dan terhadap pola-pola nilai yang dihadapi. Metode deskriptif dikelompokkan atas beberapa jenis seperti survey, studi tindakan, studi pustaka dan studi kasus (Nazir, 1999). Dalam konteks studi ini menggunakan jenis studi kasus. Perhatian utama pada pendekatan kualitatif, yaitu senantiasa menekankan pada prosedur studi yang menghasilkan data atau informasi kualitatif. Penggunaan studi kasus karena studi kasus merupakan salah satu kerangka kerja yang sangat lazim (desain studi) dan banyak digunakan dalam studi kualitatif. Sebagai suatu kategori desain studi, studi kasus tidak mudah untuk dispesifikasi dari segi akurasi dan generalisasi. Meskipun demikian, kedua aspek ini masih biasa diperdebatkan. Hal ini dapat dilihat pembahasan para ahli dalam metode kualitatif, nampak jelas pemahaman atas makna, proses pemaknaan dan produksi makna sebagaiman yang dibahas oleh interaksionisme, etnometodologi dan etnografi praktis, semuanya mengarah pada penentuan obyek yang spesifik, hal ini dapat dipenuhi dengan studi studi kasus.

Sehubungan dengan itu, ada beberapa pilihan model studi kasus yang dapat diikuti peneliti. Karena itu, dalam studi ini peneliti lebih cenderung menggunakan model studi kasus dengan "analisis data secara induktif" (induksi analitis), yaitu bertujuan untuk mencari kesamaan-kesamaan atau universalitas serta membuat kategori-kategori yang akan digunakan dalam studi ini. Alasan menggunakan analisis induktif adalah: Pertama, proses induktif lebih dapat menemukan kenyataankenyataan ganda sebagaimana yang terdapat dalam data. Kedua, analisis induktif lebih dapat membuat hubungan peneliti-informan menjadi eksplisit, dapat dikenal dan akuntabel. Ketiga, analisis demikian lebih dapat menguraikan latar secara penuh dan dapat membuat keputusan-keputusan tentang dapat tidaknya pengambilan latar lainnya. Keempat, analisis induktif lebih dapat menemukan pengaruh bersama, yang mempertajam hubungan-hubungan. Kelima, analisis demikian dapat memperhitungkan nilai-nilai secara eksplisit sebagai bagian dari struktur analitik (Moleong, 1999). 


\section{Informan Studi}

Informasi dalam studi ini diperoleh melalui wawancara mendalam, pengamatan dan observasi partisipan terhadap berbagai aktivitas dunia empirik subyek kajian. Pelaku atau informan dapat memberikan informasi tentang dirinya dan tentang keadaan orang lain yang berkaitan dengan masalah yang sedang diteliti. Berkaitan dengan itu maka alat pengumpulan data atau informasi dalam studi kualitatif adalah peneliti itu sendiri. Studi kualitatif, peneliti sekaligus merupakan perencana, penafsir dan akhirnya ia menjadi pelopor hasil studi (Muhajir, 2002). Pendekatan kualitatif memerlukan manusia sebagai instrumen karena studinya yang sarat dengan muatan naturalistik. Terkait dengan itu maka peneliti dituntut sepenuhnya memahami dan bersifat adaptif terhadap setiap situasi sosial yang dihadapi dalam kegiatan studi itu (Garna, 2004).

Berdasarkan gambaran tersebut maka informan menggunakan purposive sampling dan snowball sampling yakni orang atau pelaku yang benar-benar tahu dan menguasai masalah, serta terlibat langsung dengan masalah studi dalam studi ini dijelaskan sebagai berikut:

a. Pada level individu, informan yang dipilih adalah perempuan petani hortikultura yang berdomisili di lokasi studi. Mereka merupakan anggota kelompok wanita tani yang berjumlah 10 orang di Desa Lalonggotomi dan 10 orang di Desa Ahuawatu.

b. Pada level organisasi, informan yang dipilih adalah pengurus kelompok wanita tani yang terdiri dari ketua, bendahara dan sekretaris di Desa Lalonggotomi sedangkan di Desa Ahuawatu dipilih perempuan yang berusahatani hortikultura saja karena belum terbentuk kelompok wanita tani.

c. Pada level sistem kelembagaan di tingkat desa dipilih ibu Kepala Desa dan penyuluh pertanian lapangan (PPL) sebagai tenaga pendamping teknis kelompok wanita tani dalam usahatani hortikultura sayuran.

\section{Pengelolaan Peran Sebagai Peneliti}

Studi ini menggunakan pendekatan kualitatif maka peneliti berperan sebagai instrumen utama dan terlibat dalam aktivitas subyek studi dalam mengelola usahatani. Agar hasil yang diperoleh dapat maksimal dan permasalahan yang diteliti benar-benar sesuai dengan apa yang terjadi dan tidak menyimpang serta dapat dipertanggungjawabkan kebenarannya, maka peneliti terjun langsung di lapangan dan akan menjadi bagian dari obyek yang diteliti sehngga realitas yang terjadi dapat diketahui dan dirasakan. Dalam studi ini, peneliti sebagai instrumen dan sekaligus sebagai perencana, pelaksana, pengumpul data dan pelapor hasil studi.

Untuk mendukung studi ini maka peneliti akan memanfaatkan tacit knowledge, yakni pengetahuan yang bersifat intuitif dan dirasakan, sebagai tambahan pengetahuan yang bersifat proporsional atau pengetahuan yang dapat diekspresikan dalam bentuk bahasa karena seringkali nuansa realitas yang tidak tunggal dapat dipahami hanya dengan cara ini. Pengetahuan jenis ini juga mencerminkan secara adil dan akurat nilai-nilai penelitinya. Oleh karena itu dalam pengumpulan data, peneliti tidak hanya mencatat apa yang dinyatakan secara formal, tetapi juga mencatat berbagai hal yang dirasakan dan ditangkap secara intuitif. Data ini nantinya akan tercermin dalam bagian deskriptif dan reflektif hasil studi.

\section{Jenis dan Sumber Data}

Studi tentang peran perempuan dan strategi keberlanjutan nafkah rumahtangga petani di Kecamatan Pondidaha Kabupaten Konawe, data yang diperoleh dalam studi ini adalah data primer dan data sekunder:

1. Data primer, yakni data yang diperoleh dari hasil wawancara mendalam (indepth interview) dengan menggunakan alat bantu daftar pertanyaan, pengumpulan data dan observasi kepada pihak-pihak yang berkaitan dengan Peran Perempuan Rumahtangga Petani Hortikultura seperti Ibu Kepala Desa, Ketua Kelompok Wanita Tani dan Penyuluh pertanian.

2. Data Sekunder, yaitu data yang dikumpulkan oleh peneliti untuk mendukung data primer. Data sekunder berupa data monografi desa, dokumen-dokumen, literatur, dokumentasi dan arsip yang 
berhubungan dengan peran perempuan dan strategi keberlanjutan nafkah rumahtangga petani hortikultura.

\section{HASIL DAN PEMBAHASAN}

\section{Peran Perempuan}

Secara umum perempuan memiliki tiga fungsi utama yang sangat berkaitan dengan kedudukan dan peran perempuan, yaitu fungsi reproduksi, fungsi sosialisasi dan fungsi produksi. Fungsi reproduksi sering dihubungkan dengan hak dan kewajiban sekaligus sebagai simbol kelebihan dan kekurangan perempuan. Fungsi sosialisasi berkaitan erat dengan fungsi dan tanggung jawab dalam mempersiapkan anak-anak masuk kedalam pergaulan masyarakat luas, dimana pengasuhan dan pendidikan boleh dilakukan oleh orang lain tetapi tanggung jawabnya tetap terletak pada seorang perempuan.

Peran reproduksi perempuan pada rumahtangga petani hortikultura meliputi: 1) memasak, 2) mencuci pakaian, 3) membersihkan rumah, 4) menyiapkan makanan, 5) mengasuh anak, 6) mencuci piring, 7) mendampingi anak belajar, 8) belanja kebutuhan sehari-hari, 9) menjaga kesehatan keluarga, 10) menyetrika pakaian. Sedangkan peran produktif perempuan, meliputi: 1) pembibitan tanaman tomat, 2) penanaman bibit, 3) penyiangan, 4) penyulaman, 5) mengikat tanaman tomat, 6) buang tunas, 7) memangkas, dan 8) panen.

\section{Peran Sosial}

Selain kegiatan reproduktif dan kegiatan produktif, terdapat kegiatan lainnya yang berkaitan dengan keikutsertaan perempuan dalam organisasi atau lembaga masyarakat. Kegiatan ini dapat berupa kegiatan arisan bulanan, pengajian majelis ta'lim, syukuran (acara pernikahan, khitanan, aqiqahan) dan kegiatan kelompok wanita tani. Kegiatan yang dilakukan perempuan saja dalam rumahtangga petani hortikultura adalah kegiatan arisan, pengajian majelis ta'lim dan kegiatan kelompok wanita tani. Sedangkan kegiatan yang dilakukan bersama-sama antara perempuan dan laki-laki adalah syukuran acara pernikahan, khitanan dan aqiqahan.

\section{Strategi Keberlanjutan Nafkah}

Rumahtangga dibedakan kedalam tiga kelompok dengan strategi nafkah yang berbeda. Pertama, rumahtangga yang atau mengusahakan tanah pertanian luas, yang menguasai surplus produk pertanian diatas kebutuhan hidup mereka. Surplus ini seringkali dimanfaatkan untuk membiayai pekerjaan di luar sektor non pertanian, dengan imbalan penghasilan yang relatif tnggi pula. Pada golongan pertama, strategi pertama yang mereka terapkan adalah srategi akumulasi dimana hasil pertaniannya mampu diinvestasikan kembali baik pada sektor pertanian maupun non pertanian. Kedua, rumahtangga usaha tani sedang mereka biasanya bekerja pada sektor non pertanian dalam upaya melindungi diri dari gagal panen atau memberikan sumber pendapatan yang berkelanjutan mengingat usaha pertanian bersifat musiman. Strategu mereka ini dapat disebut strategi konsolidasi. Ketiga, rumahtangga usaha tani gurem atau tidak bertanah. Biasanya mereka bekerja dari usaha tani ataupun buruh tani, dimana penghasilannya tidak dapat mencukupi kebutuhan dasar. Rumahtangga ini akan mengalokasikan sebagian dari tenaga kerja mereka tanpa modal, dengan imbalan yang rendah ke dalam kegiatan luar pertanian. Pada rumahtangga golongan ketiga ini menerapkan strategi bertahan hidup atau survival strategy (White,1990).

\section{Rekayasa Sumber Nafkah Pertanian}

Mayoritas penduduk Desa Lalonggotomi dan Desa Ahuawatu berprofesi sebagai petani padi sawah. Sebenarnya, pertanian hortikultura utamanya tomat dan cabai membutuhkan modal yang tidak sedikit namun apabila dikelola dengan baik dan harga bagus, hal tersebut dapat menutupi biaya produksi dan bahkan mendapatkan keuntungan yang dapat menambah penghasilan keluarga. Selain budidaya padi sawah yang mereka lakukan, tanaman tomat yang mereka usahakan mampu menutupi 
kebutuhan dasar mereka. Sebagian perempuan didua desa tersebut juga melakukan budidaya tanaman yang berumur pendek seperti tanaman bayam, kangkung, sawi, dan mentimun. Selain budidayanya yang mudah dilakukan hasilnya juga cepat didapatkan.

\section{Pola Nafkah Ganda}

Pola nafkah ganda merupakan salah satu strategi yang dilakukan oleh rumahtangga petani hortikultura di Desa Lalonggotomi dan Ahuawatu. Strategi yang dilakukan untuk menambah pendapatan adalah mencari pekerjaan tambahan di luar usahatani hortikultura. Pola nafkah ganda dapat dilakukan dengan berbagai cara yang pada intinya tidak hanya memanfaatkan satu sumber nafkah saja. Pola nafkah ganda juga dilakukan dengan mengerahkan tenaga kerja keluarga (ibu dan anak) untuk ikut bekerja selain pada sektor pertanian. Berdasarkan hasil studi, diketahui bahwa beberapa ibu rumahtangga di kedua desa tersebut melakukan pola nafkah ganda untuk menghasilkan pendapatan. Selain menjadi petani hortikultura mereka juga menjdi petani padi sawah, beberapa perempuan ada yang menjadi buruh pemetik tomat dan cabai pada saat panen tiba, ada yang jualan keliling, membuka warung, menjahit dan jualan sayur di pasar.

\section{Pemanfaatan Pinjaman}

Keterbatasan modal yang dimiliki dalam bercocok tanam mendorong petani untuk melakukan sesuatu yang bisa menopang aktivitas mereka ditengah keterbatasan tersebut. Selain untuk modal bertani petani membutuhkan uang untuk mencukupi kebutuhan hidup sehari-hari atau untuk kebutuhan pendidikan anak. Petani melakukan berbagai macam cara untuk bertahan hidup dan salah satu adalah memanfaatkan modal sosial dengan cara meminjam uang kepada pemilik modal.

\section{Pemanfaatan Asset}

Strategi lain yang rumahtangga lakukan adalah menjual aset pribadi yang berharga untuk memenuhi biaya pendidikan anak dan kebutuhan sehari-hari yang cukup besar. Penjualan aset merupakan langkah yang ditempuh petani ketika sudah terdesak seperti biaya pendidikan anak, atau untuk modal usahatani dan bahkan untuk memenuhi kebutuhan hari-hari. Asset yang dimiliki petani dikedua desa adalah berupa ternak sapi. Sumber livelihood rumah tangga petani hortikultura dapat diklasifikasikan dengan menggunakan kerangka Ellis (2000), yang mengklasifikasi sumber nafkah menjadi tiga yaitu basis on farm, off farm dan non farm. Berdasarkan informasi yang dikumpulkan dalam studi ini, rumahtangga petani hortikultura tidak hanya berpatok pada satu sumber mata pencaharian saja melainkan lebih dari satu sumber mata pencaharian.

\section{Strategi Keberlanjutan Nafkah Rumahtangga Petani Hortikultura}

Menurut Ellis (2000) terdapat tiga aspek pembentuk strategi nafkah, yakni dari on-farm, off-farm dan non-farm. On farm merupakan strategi nafkah yang didasarkan dari hasil sumber pertanian dalam arti luas (perkebunan, pertanian, kehutanan, peternakan dan perikanan). Off farm dapat berupa upah tenaga kerja pertanian, sistem bagi hasil (harvest share system), kontrak upah tenaga kerja non upah dan lain-lain. Non-farm sumber pendapatan berasal dari luar kegiatan pertanian.

Variasi nafkah seseorang dipengaruhi oleh pendidikan dan keterampilannya. Variasi nafkah juga dipengaruhi oleh peluang lapangan kerja. Baik di Desa Lalonggotomi maupun di Desa Ahuawatu, lapangan pekerjaan bidang pertanian masih luas sehingga masyarakat enggan mencoba pekerjaan yang lain.

\section{V.KESIMPULAN}

Perempuan yang melakukan kegiatan (reproduktif, produktif dan sosial) tergolong kategori tinggi. Strategi yang dilakukan untuk keberlanjutan nafkah rumahtangga berupa : a) rekayasa sumber nafkah pertanian, dengan pemanfaatan sektor pertanian secara efektif dan efisien, penambahan tenaga kerja, menggunakan inovasi teknologi terbaru serta perluasan lahan garapan; b) pola nafkah ganda, selain 
membantu suami kerja di lahan juga ada yang membuka warung sembako, menjual makanan jadi, menjual sayur keliling, menjahit, menjual beras, c) pemanfaatan pinjaman dan, d) pemanfaatan asset.

\section{DAFTAR PUSTAKA}

Abdullah, Irwan. 1997. Sangkan Peran Gender. Pustaka Pelajar. Yogyakarta.

Arikunto, S. 1986. Prosedur Studi Suatu Pendekatan Praktik. Rineka Cipta. Jakarta.

Astuti, 2013. Peran Ibu Rumahtangga dalam Meningkatkan Kesejahteraan Keluarga (Suatu Kajian Pemenuhan Kebutuhan Pendidikan Anak pada 5 Ibu Pedagang Jambu Biji di Desa Bejen Kecamatan Bejen Kabupaten Temanggung. Skripsi. Jurusan Pendidikan Luar Sekolah. Fakultas Ilmu Pendidikan. Universitas Negeri Semarang.

Bebbington, Anthony. 1999. Capital and Capabilities: A fremework for Analyzing Peasant Viability, Rural Livelihood and Poverty. World Development. Vol. 27 (12): 2021-2044.

Black, A. James dan Champion J. Dean. Metode Dan Masalah Studi Sosial. Penerbit Refika Aditama. Bandung.

Carner, G. 1984. Survival, Interpedence and Competition Among the Phillippine Rural Poor. People Centered Development. Kumarian Press. Connecticut.

Conway, G dan R. Chambers. 1991. Sustainable Rural Livelihood: Practical Concept for 21st Century, IDS Discussion Paper 296: IDS. Institute For Development Studies. Brighton.

Chambers, Robert. 1995. Poverty and Livelihood: Whose Reality Counth?. Journal : Environtment and Urbanization. Vol. 7 (1).

Creswell, W. John. 1994. Research Design Qualitative \& Quantitative Approaches. Sage Publication. London New Delhi.

Crow, G. 1989. The use of the concept of strategy in recent sosiological literature. Sociology, Volume $23(1)$.

Damayanti, R. 2003. Strategi Adaptasi Perempuan Pedesaan: Persoalan Ekonomi dan Upaya Pengorganisasian. Jurnal Analisis Sosial. Vol. 8 (2).

Dharmawan, A. H. 2001. Farm Household Livelihood Strategis and Socioeconomic Changes in Rural Indonesia. Kiehl : Wissenschaftsverlag Vaug Kiehl KG

2001. Farm Household Livelihood Strategis and Socioeconomic Changes in Rural Indonesia : A Comparative Studies. Socio-economic Studies on Rural Development. Vol. 124. 